\title{
PHYSIOLOGICAL AND BIOCHEMICAL CHANGES IN WATERLOG TOLERANT SESAME GENOTYPES
}

\author{
R. R. Saha ${ }^{* 1}$, F. Ahmed ${ }^{2}$, N. Mokarroma ${ }^{3}$, M. M. Rohman ${ }^{4}$ and P. C. Golder ${ }^{5}$ \\ ${ }^{1}$ Crop Division, Bangladesh Agricultural Research Council, Dhaka-1215 \\ ${ }^{2}$ Plant Physiology Division, Bangladesh Agricultural Research Institute, Gazipur-1701 \\ ${ }^{3}$ Plant Physiology Division, Bangladesh Agricultural Research Institute, Gazipur-1701 \\ ${ }^{4}$ Plant Breeding Division, Bangladesh Agricultural Research Institute, Gazipur-1701 \\ ${ }^{5}$ Member Director, Planning and Evaluation, Bangladesh Agricultural Research Council, \\ Dhaka-1215
}

\begin{abstract}
An experiment was conducted under pot culture to investigate physiological responses as well as antioxidative enzymes activities that may lead to select sesame genotype (s) which were more waterlogging tolerant at vegetative stage. Four sesame genotypes viz. BD-6980, BD6985, BD-6992 and BD-7012 were grown under waterlogged (at vegetative stage) and control (no waterlogged) conditions. Plant height, root length, root volume, root dry weight and leaf area per plant in all the four sesame genotypes significantly decreased due to waterlogging at vegetative stage in comparison to controlled condition. Higher SPAD value (Soil and Plant Analyzer Development) and specific leaf mass were recorded in waterlogged plant than controlled plant during waterlogging period but reverse was the case during recovery period. All the genotypes showed positive indices of waterlogging tolerance in terms of better performance of root, stem, leaf and petiole. Among the genotypes, BD 6980 showed higher waterlogging tolerance in all the components followed by BD 6985. Malondialdehyde (MDA) content was found higher in waterlogged plant of all the four sesame genotypes in both waterlogging period and recovery period than the controlled plant. Antioxidant enzyme activities like Peroxidase (POD), Catalase (CAT), Ascorbate peroxidase (APX), Glutathione peroxidase (GPX) and Superoxide dismutase(SOD) were inconsistent in the present study but most of the antioxidant enzyme activities showed an increasing trend in waterlogged plant than that of control plant in all the genotypes. Comparatively low amount of MDA content and high antioxidant activities of sesame genotype BD 6980 is considered as highly tolerant to waterlogging and other three genotypes are moderately tolerant under water logging condition.
\end{abstract}

\footnotetext{
* Corresponding author email: saharinarani@yahoo.com
} 
Keywords: Biochemical, genotypes, physiological, sesame, tolerant, waterlogging

\section{INTRODUCTION}

In Bangladesh, sesame is mainly grown in Kharif season which is the dry wet transition period due to the start of monsoon and quite often it is affected by waterlogging condition. Waterlogging is a worldwide phenomenon that affects crop yield. Waterlogging occurs in saturated soils, when the air filled porosity falls below $10 \%$ (Hodgsen and Chan, 1982). In a well drained soil, the air filled porosity usually ranges from 10 to $40 \%$ of total soil volume but waterlogging reduces these pores, substantially diminishing root oxygen supply causing hypoxia (Barrett Lennard, 2003; Boru et al., 2003; Colmer and Islam, 2002). As oxygen diffuses 10,000 times more slowly in water than in air (Armstrong, 1979), plant tissues became hypoxic under anoxic condition since roots require oxygen for optimal respiration and metabolic activity. Waterlogging situation results in anaerobic respiration and causes injury and reduction in growth of root as well as shoots (Kramer, 1951). Physiological consequences of waterlogged conditions include altered shoot and root hormonal status (Hocking et al., 1985) and nutrient uptake (Orchard et al., 1986; Rochester, 2001, Wiengweera and Greenway, 2004). Furthermore, waterlogging causes the closure of stomata, reduction in $\mathrm{CO}_{2}$ concentration and therefore a decline in photosynthesis (Crawford, 1978) and consequently it might also increase the concentration of damaging reactive oxygen species (ROS) inside the plant cells. In recent past, it was observed that the reproductive stage of sesame is very much sensitive to waterlogging than that of vegetative stage (Saha et al., 2010). However, oxidative stress reactions in plant cells are associated with toxic free radicals from the reduction of molecular oxygen to the super oxide radical, singlet oxygen, hydroxyl radical and hydrogen peroxide (Bowler et al., 1992). A major safe guarding mechanism against free radicals is provided by SOD, which catalyzes the conversion of $\mathrm{O}_{2}$ to $\mathrm{H}_{2} \mathrm{O}_{2}$ then $\mathrm{H}_{2} \mathrm{O}_{2}$ is decomposed in the presence of catalase (CAT) and peroxidase (POD). However, very little information is available about the response of the antioxidative system when sesame plants are subjected to waterlogging conditions. With this view the present study was undertaken to investigate physiological responses as well as antioxidative enzymes activities of our moderately tolerant against waterlogging genotypes of sesame (BD-6980, BD-6985, BD-6992 and BD-7012) that may lead to select sesame genotype (s) which were more waterlogging tolerant at vegetative stage.

\section{MATERIALS AND METHODS}

The experiment was carried out at the Bangladesh Agricultural Research Institute, Joydebpur, Gazipur during March to June 2014. The experiment was laid out in completely randomized design with three replications. Sesame was grown in earthen pot containing around $12 \mathrm{~kg}$ soil collected from Kodda, Kaliakoir, Upazila, 
Gazipur district of Bangladesh. Treatments consists of four moderately waterlogged tolerant genotypes of sesame (viz., BD-6980, BD-6985, BD-6992 and BD-7012) subjected to waterlogged (at vegetative stage) and control (no waterlogged) conditions. Application of fertilizers @ 100-130-40-100 kg ha ${ }^{-1}(0.6-0.78-0.24-0.6 \mathrm{~g}$ pot $\left.^{-1}\right)$ of urea, triple super phosphate, muriate of potash and gypsum. Every pot was hand weeded at 21 and 35 days after sowing. For controlling hairy caterpillar Ripcord @ $1 \mathrm{ml}$ litre $^{-1}$ of water was sprayed at 45 and 60 days after sowing. In each pot, 10 seeds were sown on 2 March, 2014. The seedlings were emerged within 7 days after sowing. At 21 days after sowing, seedlings were thinned out keeping two uniform seedlings in each pot. Waterlogging condition was imposed at 29 days after emergence (DAE) and kept waterlogging (3-5 cm water above the soil surface) for three days. These three days (29-30 DAE) were considered as waterlogging period and onward removal of waterlogging i.e., 32-43 DAE was considered as recovery period. Plants from three pots for every genotype under both waterlogged and control condition were collected after termination at waterlogging (31 DAE) and 12 days after termination of waterlogging i.e., $43 \mathrm{DAE}$ (recovery period) to record data on different parameters such as SPAD value, leaf area, root-shoot length, root volume and components dry weight. Specific leaf mass (SLM) was determined as the ratio between leaf dry weight and leaf area following Hunt (1978). Leaf area was measured immediately after collection of the plant with the help of an automatic leaf area meter (LI 3100, LI-COR, USA). The relative growth rate (RGR) of plant components biomass and total biomass were calculated according to Gardner et al. (1985). The RGR of each plant component under waterlogged and control conditions were calculated. Waterlogging tolerance (WLT) indices of different components was calculated as percent ratio of RGR of waterlogged plants to RGR of control plants indicating the degree of tolerance of sesame genotypes under waterlogging condition (Chan and Burton, 1992). Biochemical analysis was done at Molecular Laboratory of Plant Breeding Division, BARI, Gazipur. Protein concentration in the leaf extract was determined according to the method of Bradford (1976) using BSA as a protein standard. Peroxidase (POD) activity was estimated according to Hemeda and Klein (1990). Superoxide dismutase (SOD) activity was determined using an indirect competitive inhibition assay (Spitz and Oberley, 1989). Ascorbate peroxidase (APX) activity was assayed following the method of Nakano and Asada (1981). Glutathione peroxidase (GPX) activity was measured as described by Elia et al. (2003). Catalase (CAT) activity was measured according to the method of Csiszár et al. (2007). The level of lipid peroxidation was measured by estimating MDA following the method of Heath and Packer (1968). Mean and standard deviation/standard error of collected data were analyzed statistically. 


\section{RESULTS AND DISCUSSION}

\section{Morphophysiological changes}

Plant height and root length in both waterlogging period and recovery period were shorter due to waterlogging than that of control condition (Figure 1 and 2).

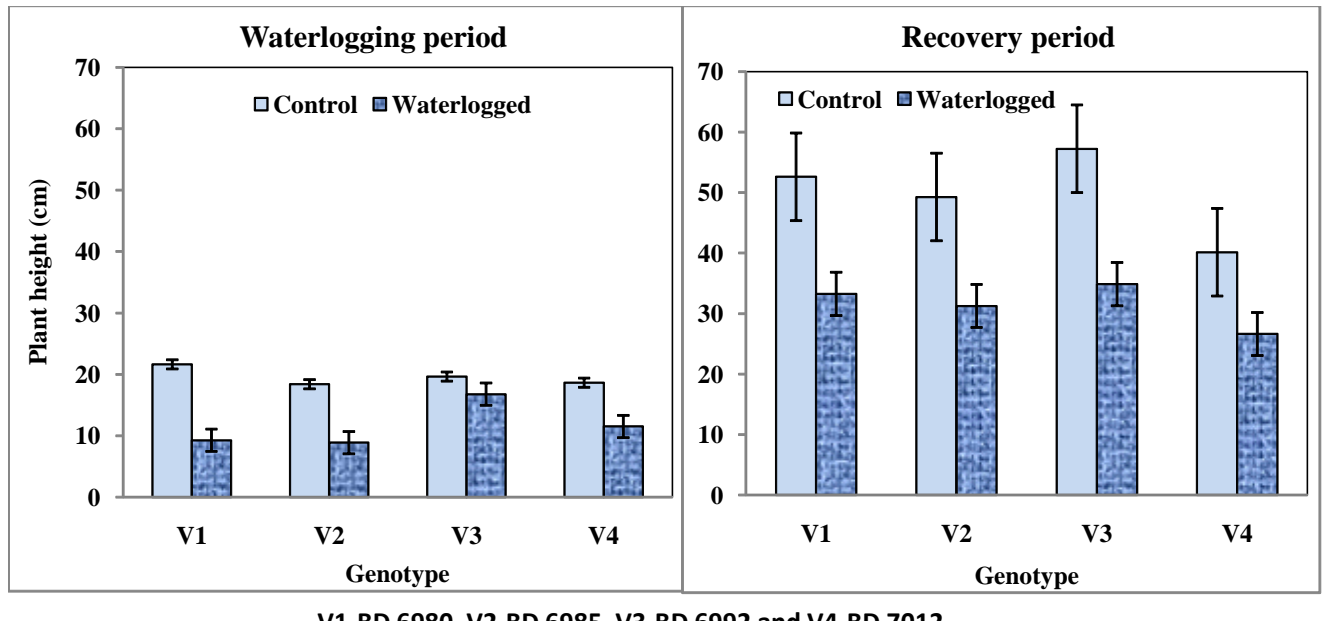

Figure1. Plant height of four sesame genotypes under waterlogging at vegetative stage during waterlogging and recovery period. Vertical bar indicates the standard error.

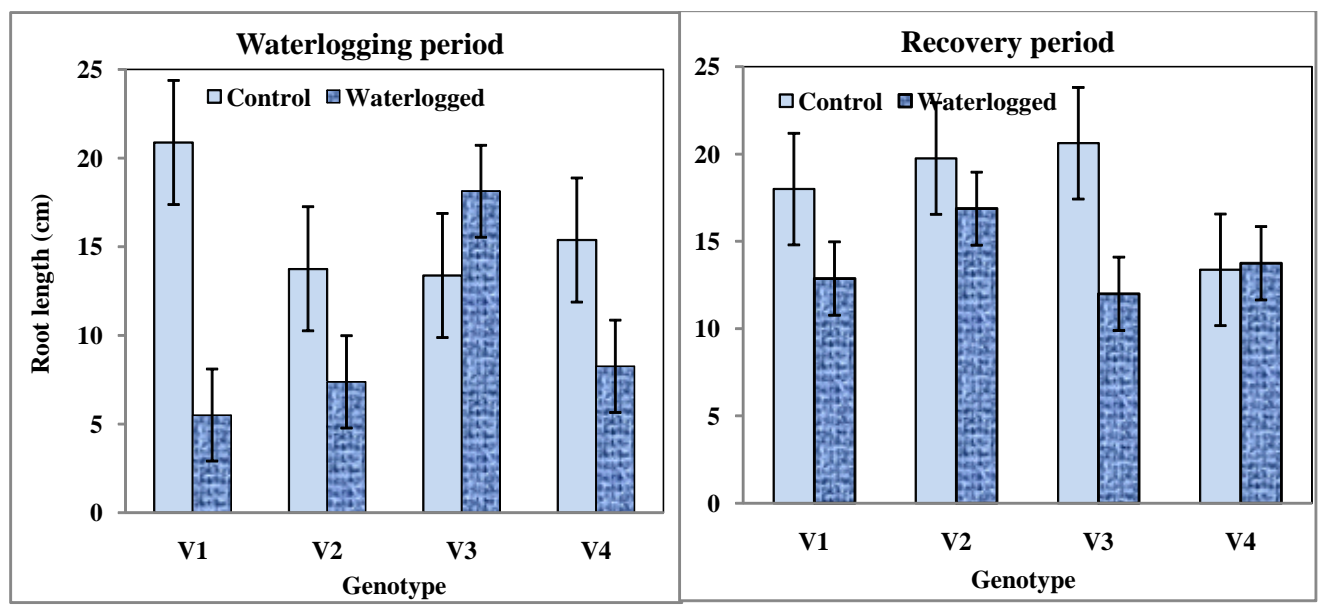

V1-BD 6980, V2-BD 6985, V3-BD 6992 and V4-BD 7012

Figure 2. Root length of four sesame genotypes under waterlogging at vegetative stage during waterlogging and recovery period. Vertical bar indicates the standard error. 
Plant height of genotypes BD-6980 ( $\left.\mathrm{V}_{1}\right)$, BD-6985 $\left(\mathrm{V}_{2}\right)$, BD-6992 $\left(\mathrm{V}_{3}\right)$, BD-7012 $\left(\mathrm{V}_{4}\right)$ at waterlogging period and recovery period were $9.3,8.9,16.8,11.5 \mathrm{~cm}$ and $33.3,31.3,34.9,26.6 \mathrm{~cm}$ of waterlogging treated plant whereas 21.6, 18.4, 19.6, $18.6 \mathrm{~cm}$ and $52.6,49.3,57.3,40.1 \mathrm{~cm}$ of untreated control plant. Similarly root length in both waterlogging period and recovery period among the genotypes $V_{1}, V_{2}, V_{3} V_{4}$ were $5.5,7.4,18.1,8.3 \mathrm{~cm}$ and $12.9,16.9,12.0,13.8 \mathrm{~cm}$ of waterlogging treated plant whereas $20.9,13.8,13.4,15.4 \mathrm{~cm}$ and $18.0,19.8,20.6,13.4 \mathrm{~cm}$ of untreated control plant.

Root volume and root dry weight also substantially reduced in response to waterlogging (Figure 3 and 4). It was observed that root volume reduced 66-85\% at waterlogging period and $15-57 \%$ at recovery period in waterlogging treated plant of different genotypes compared to untreated control plant.

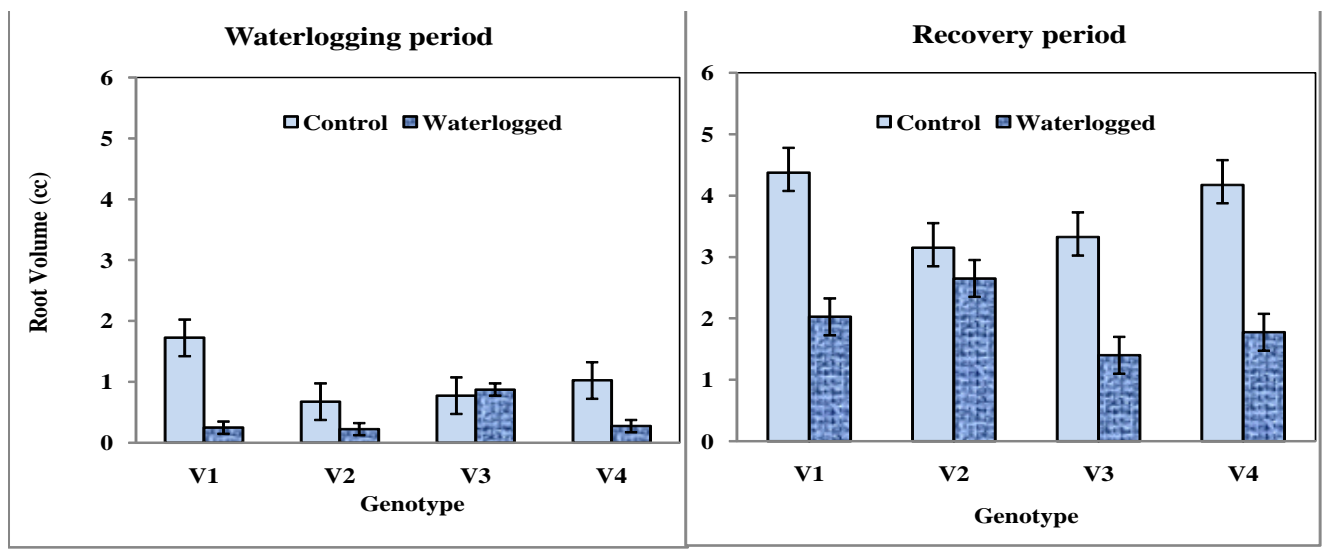

V1-BD 6980, V2-BD 6985, V3-BD 6992 and V4-BD 7012

Figure 3. Root volume of four sesame genotypes under waterlogging at vegetative stage during waterlogging and recovery period. Vertical bar indicates the standard error.

In case of root dry weight it was reduced $28-81 \%$ at waterlogging period and $57-69 \%$ at recovery period in waterlogging treated plant compared to untreated control plant. 


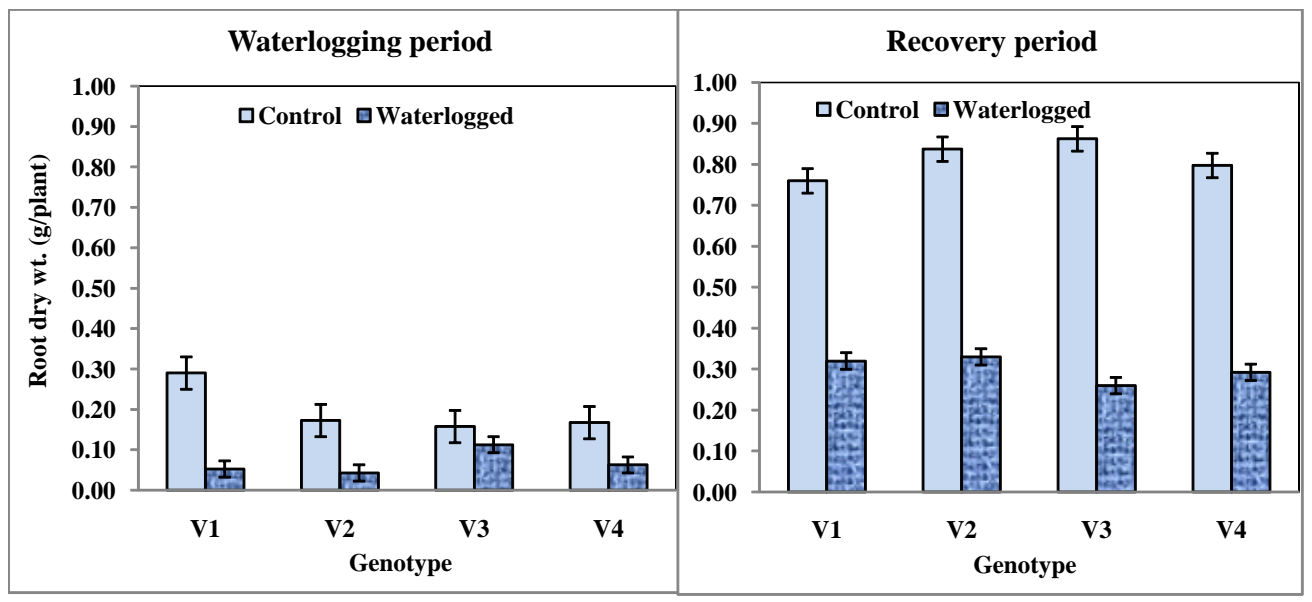

V1-BD 6980, V2-BD 6985, V3-BD 6992 and V4-BD 7012

Figure 4. Root dry weight of four sesame genotypes under waterlogging at vegetative stage during waterlogging and recovery period. Vertical bar indicates the standard error.

Leaf area also found smaller in all the genotypes i.e., 75 to $134 \mathrm{~cm}^{2}$ and 244 to $297 \mathrm{~cm}^{2}$ in waterlogging affected plant whereas 152 to $258 \mathrm{~cm}^{2}$ and 399 to $509 \mathrm{~cm}^{2}$ during waterlogging period and recovery period, respectively (Figure 5).

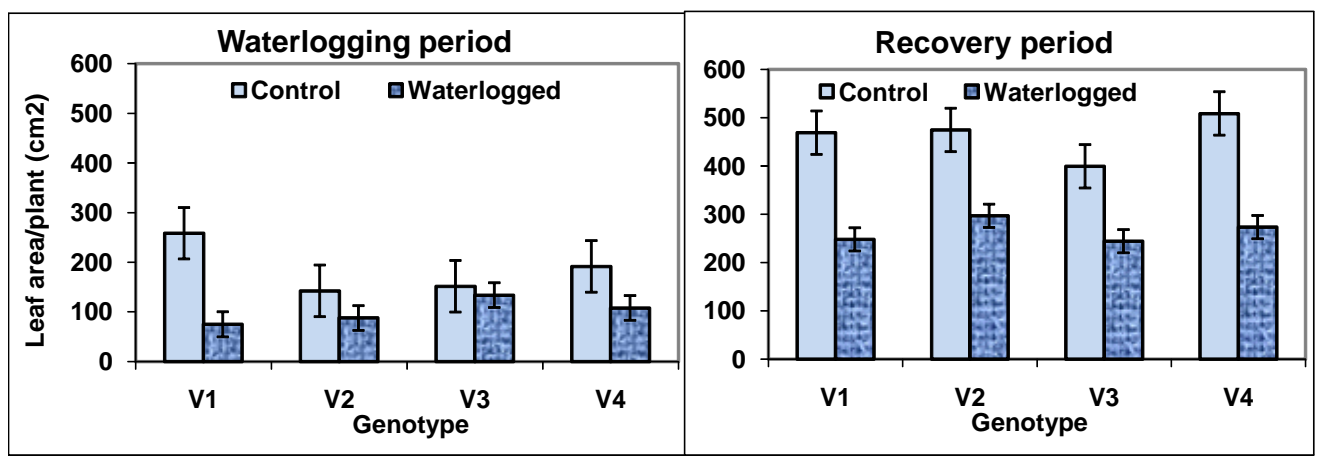

V1-BD 6980, V2-BD 6985, V3-BD 6992 and V4-BD 7012

Figure 5. Leaf area of four sesame genotypes under waterlogging at vegetative stage during waterlogging and recovery period. Vertical bar indicates the standard error.

SPAD reading which is the indicator of chlorophyll content of leaf showed higher value ( 40.7 to 44.4 ) in waterlogged plant than that of control plant (37.5 to 41.8) during waterlogging but it showed decreasing trend (38.7 to 40.7) in waterlogged plant than that of control plant (43.7 to 46.9) during recovery period (Figure 6). 


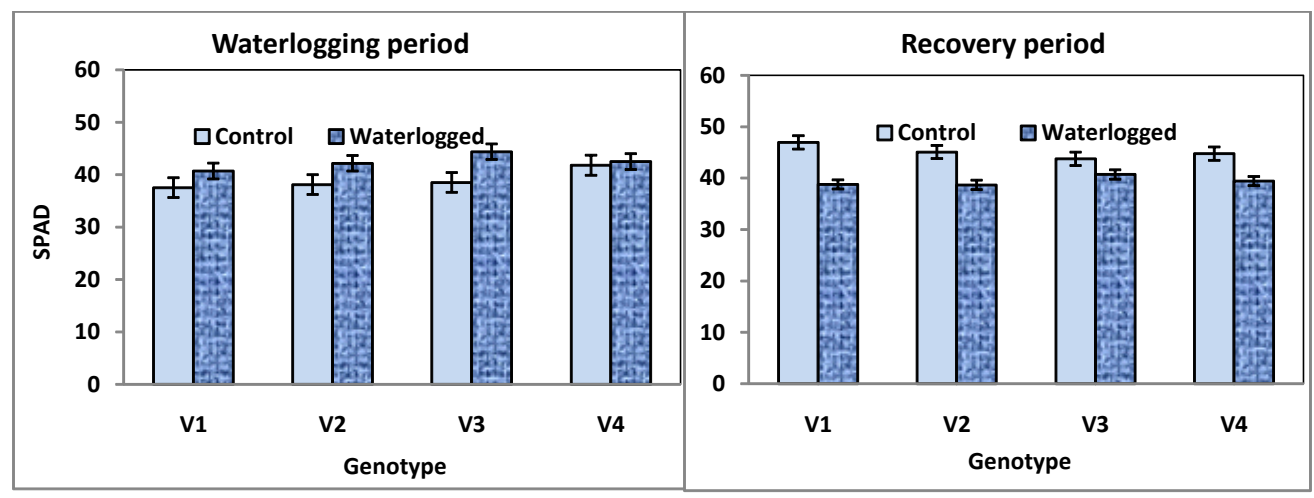

V1-BD 6980, V2-BD 6985, V3-BD 6992 and V4-BD 7012

Figure 6. SPAD value of four sesame genotypes under waterlogging at vegetative stage during waterlogging and recovery period. Vertical bar indicates the standard error.

Specific leaf mass also showed the similar trend with that of SPAD value (Figure 7). Specific leaf mass of different genotypes showed increasing trend (5.48 to 6.33 ) in waterlogged plant than that of control plant (3.97 to 5.82) during waterlogging but it showed decreasing trend (4.86 to 5.87) in waterlogged plant than that of control plant (5.34 to 6.29) during recovery period. From these results it indicated that waterlogging stunted the leaf expansion but leaf content might be concentrated during the waterlogging period resulting the higher SPAD value as well as greater specific leaf mass. But during recovery period, waterlogged plant started to expand leaf size or produce new leaf which might have lower SPAD value and specific leaf mass under waterlogged plant than that of control plant.

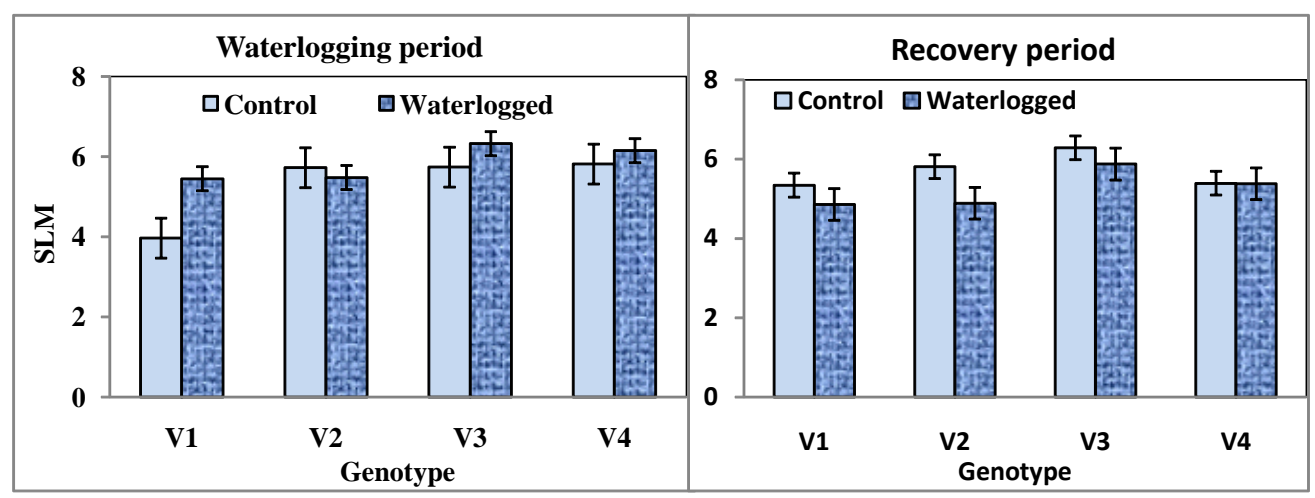

V1-BD 6980, V2-BD 6985, V3-BD 6992 and V4-BD 7012

Figure 7. Specific leaf mass (SLM) of four sesame genotypes under waterlogging at vegetative stage during waterlogging and recovery period. Vertical bar indicates the standard error. 
Dry matter partitioning pattern of different components showed the lesser amount of dry mass in all the plant parts in waterlogged plant than that of control plant in both the waterlogging period and recovery period regardless of genotypes (Figure 8).

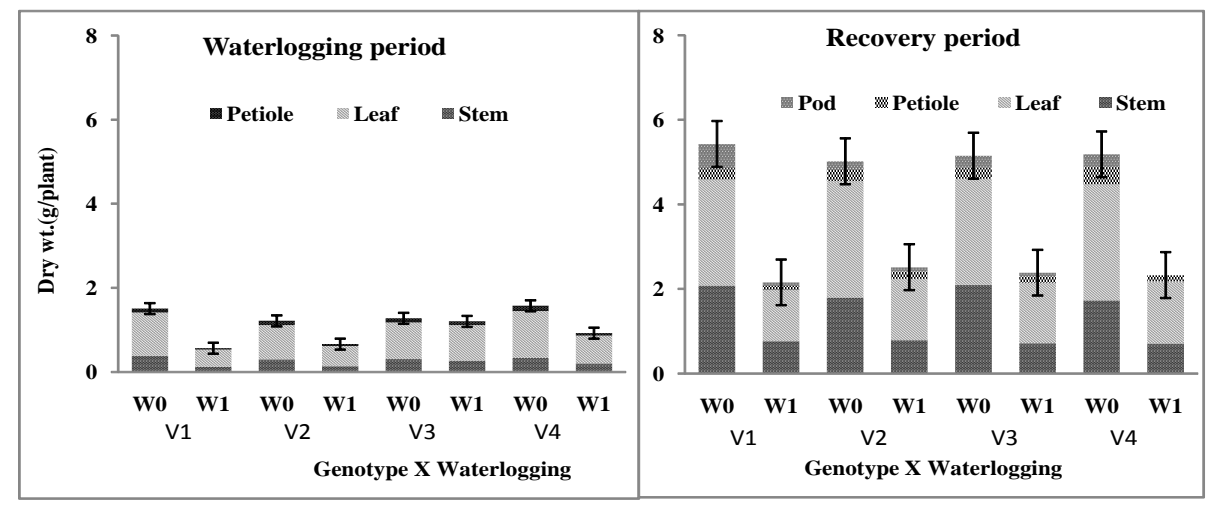

W0- Control \& W1-Waterlogged; V1-BD 6980, V2-BD 6985, V3-BD 6992 and V4-BD 7012

Figure 8. Dry matter partioning of four sesame genotypes under waterlogging at vegetative stage during waterlogging and recovery period. Vertical bar indicates the standard error.

Root and shoot ratio decreased in waterlogged plant (0.06 to 0.09 and 0.11 to $0.15)$ compared to that of control plant $(0.11$ to 0.19 and 0.14 to 0.17$)$ in waterlogging period and recovery period, respectively (Figure 9). It was also observed that decreasing trend was slightly lower during recovery period than that of waterlogging period. It indicated that the plant might be recovered its root system compared to shoot.

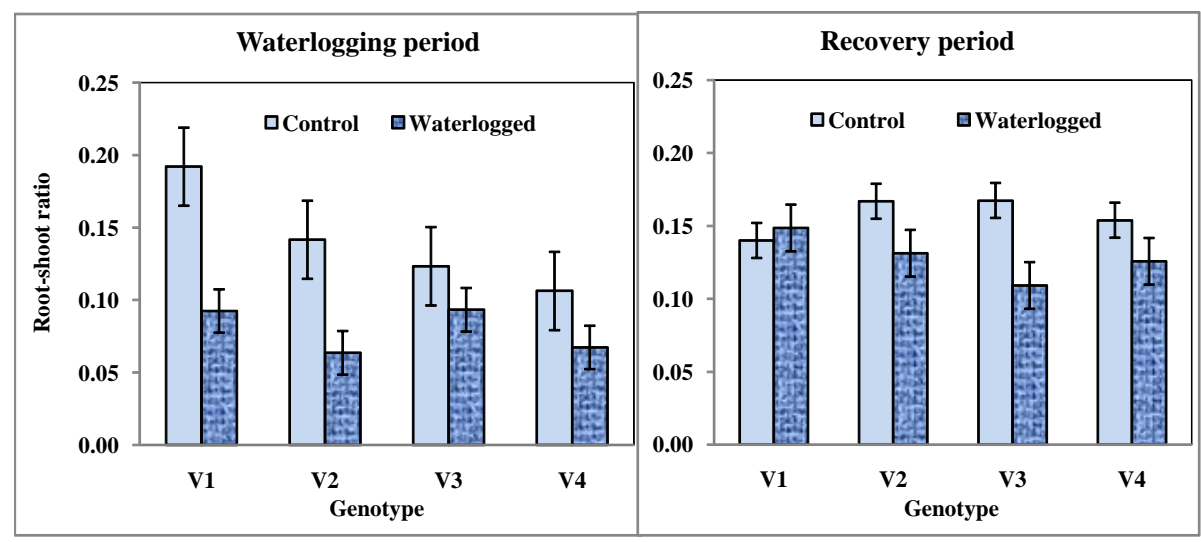

V1-BD 6980, V2-BD 6985, V3-BD 6992 and V4-BD 7012

Figure 9. Root-shoot ratio of four sesame genotypes under waterlogging at vegetative stage during waterlogging and recovery period. Vertical bar indicates the standard error. 


\section{Relative growth of plant components and waterlogging tolerance}

The relative growth rate (RGR) of root, stem, leaf, petiole, shoot and total plant of both waterlogged and control condition of four sesame genotypes during recovery period showed the positive RGR in all the genotypes under control as well as waterlogged condition (Table 1). Among the genotypes, BD 6980 showed identical or greater values i.e., $0.15,0.15,0.09,0.08,0.11$ and 0.12 RGR of root, stem, leaf, petiole, shoot and total plant of waterlogged plant compared to control plant $(0.01,0.14,0.07,0.09,0.11$ and 0.10 RGR of root, stem, leaf, petiole, shoot and total plant). Among the components, RGR of root under waterlogged condition was found higher $(0.15,0.18$, and 0.13$)$ or similar compared to control condition $(0.01$, 0.13 and 0.13) in all genotypes except BD 6992 (0.07 RGR at waterlogged plant and 0.14 RGR at control plant). Waterlogging tolerance (WLT) indices of root showed better performance except BD 6992. Among the genotypes,BD 6980 exhibited greater tolerance indices i.e., nearly $100 \%$ or more than $100 \%$ followed by BD 6985 which indicated the highly tolerant against waterlogging.

Table 1. Relative growth rate (RGR, g/g/day) and waterlogging tolerance (WLT, \%) of plant components of four sesame genotypes.

\begin{tabular}{|c|c|c|c|c|c|c|c|}
\hline Genotypes & $\begin{array}{l}\text { RGR and } \\
\text { WLT }\end{array}$ & Root & Stem & Leaf & Petiole & Shoot & Total plant \\
\hline \multirow{3}{*}{ BD 6980} & Waterlogged & 0.15 & 0.15 & 0.09 & 0.08 & 0.11 & 0.12 \\
\hline & Control & 0.01 & 0.14 & 0.07 & 0.09 & 0.11 & 0.10 \\
\hline & WLT $(\%)$ & 150 & 108 & 128 & $\mathbf{8 8}$ & 100 & 112 \\
\hline \multirow{3}{*}{ BD 6985} & Waterlogged & 0.18 & 0.15 & 0.09 & 0.10 & 0.11 & 0.12 \\
\hline & Control & 0.13 & 0.15 & 0.10 & 0.09 & 0.12 & 0.12 \\
\hline & WLT (\%) & 132 & 100 & 90 & 111 & 92 & 100 \\
\hline \multirow{3}{*}{ BD 6992} & Waterlogged & 0.07 & 0.08 & 0.04 & 0.04 & 0.06 & 0.06 \\
\hline & Control & 0.14 & 0.16 & 0.09 & 0.08 & 0.12 & 0.12 \\
\hline & WLT $(\%)$ & 50 & 50 & 44 & 50 & 50 & 50 \\
\hline \multirow{3}{*}{ BD 7012} & Waterlogged & 0.13 & 0.10 & 0.07 & 0.08 & 0.08 & 0.08 \\
\hline & Control & 0.13 & 0.14 & 0.08 & 0.10 & 0.10 & 0.10 \\
\hline & WLT (\%) & 100 & 71 & 88 & 80 & 80 & 80 \\
\hline
\end{tabular}

\section{Enzymatic Activities}

Different enzymatic activities of the youngest fully expanded green leaves of sesame under control and waterlogged plants in both waterlogging period and recovery period Revealed that the injury of biological lipid by reactive oxygen species (ROS) as indicated by Malondialdehyde (MDA) content was higher (14.41 to $14.70 \mathrm{nmol} \mathrm{g}{ }^{-1} \mathrm{FW}$ and 10.66 to $22.03 \mathrm{nmol} \mathrm{g}{ }^{-1} \mathrm{FW}$, respectively) in waterlogged 
plant of all the four sesame genotypes in both waterlogging period and recovery period than controlled plants $\left(9.92\right.$ to $13.7 \mathrm{nmol} \mathrm{g}^{-1} \mathrm{FW}$ and 8.42 to $18.27 \mathrm{nmol} \mathrm{g}^{-1}$ FW) (Table 2 and 3). However, the rate of increment was lower in BD 6980 during waterlogging period which indicated that lesser oxidative stress injury than that of other genotypes. Different antioxidative enzyme activities including superoxide dismutase (SOD), peroxidase (POD), catalase (CAT), ascorbate peroxidase (APX) and glutathione peroxidase (GPX) to encounter the deleterious effects of ROS showed differential responses in different genotypes due to imposition of waterlogging. SOD activity increased in BD 6980 and BD 6985 genotypes but decreased in BD 6992 and BD 7012 genotypes during waterlogging period. But it increased in all genotypes during recovery period. Catalase activities showed increasing trend at waterlogged plant in all the genotypes during both waterlogging and recovery period except BD 6985 during recovery period. Different peroxidase activities such as POD, APX and GPX increased in waterlogged plant in all genotypes than that of control plant during both waterlogging and recovery period except slightly reduced activity of GPX in BD 6980 during recovery period.

Table 2. Enzymatic activities among the sesame genotypes during waterlogging period

\begin{tabular}{|c|c|c|c|c|c|c|c|}
\hline Genotypes & Treatment & $\begin{array}{c}\text { POD } \\
(\mu \mathrm{mol} / \\
\text { min/mg } \\
\text { protein) }\end{array}$ & $\begin{array}{c}\text { CAT } \\
(\mu \mathrm{mol} / \\
\mathrm{min} / \mathrm{mg})\end{array}$ & $\begin{array}{c}\mathrm{APX} \\
(\mu \mathrm{mol} / \mathrm{min} \\
/ \mathrm{mg} \\
\text { protein })\end{array}$ & $\begin{array}{c}\text { GPX } \\
\text { (nmol/ } \\
\text { min/mg } \\
\text { protein) }\end{array}$ & $\begin{array}{c}\text { SOD } \\
\text { (U/mg } \\
\text { protein }\end{array}$ & $\begin{array}{c}\text { MDA } \\
(\mathrm{nmol} / \mathrm{g} \\
\mathrm{FW})\end{array}$ \\
\hline \multirow{3}{*}{ BD 6980} & Control & $0.23 \pm 0.03$ & $15.3 \pm 2.6$ & $2.68 \pm 0.3$ & $310.0 \pm 30.9$ & $152.6 \pm 9.1$ & $13.7 \pm 0.5$ \\
\hline & waterlogged & $0.39 \pm 0.05$ & $17.9 \pm 2.8$ & $7.1 \pm 0.1$ & $798.7 \pm 38.1$ & $168.9 \pm 18.5$ & $14.5 \pm 0.3$ \\
\hline & $\begin{array}{l}\text { Relative } \\
\text { change }(\%)\end{array}$ & 70.50 & 17.07 & 163.19 & 157.66 & 10.63 & 5.79 \\
\hline \multirow{3}{*}{ BD 6985} & Control & $0.52 \pm .08$ & $21.2 \pm 1.1$ & $9.1 \pm 0.2$ & $336.7 \pm 32.9$ & $143.7 \pm 6.7$ & $12.4 \pm 0.7$ \\
\hline & waterlogged & $0.54 \pm 0.13$ & $43.5 \pm 4.3$ & $11.0 \pm 0.9$ & $613.5 \pm 101.3$ & $190.8 \pm 11.9$ & $14.6 \pm 1.1$ \\
\hline & $\begin{array}{l}\text { Relative } \\
\text { change }(\%)\end{array}$ & 3.92 & 104.55 & 21.70 & 82.19 & 32.75 & 17.64 \\
\hline \multirow{3}{*}{ BD 6992} & Control & $0.05 \pm 0.01$ & $29.2 \pm 1.5$ & $1.5 \pm 0.07$ & $250.7 \pm 9.0$ & $140.5 \pm 16.0$ & $13.0 \pm 1.2$ \\
\hline & waterlogged & $0.11 \pm 0.01$ & $36.8 \pm 3.0$ & $2.7 \pm 0.33$ & $583.3 \pm 28.8$ & $109.9 \pm 5.2$ & $14.4 \pm 0.6$ \\
\hline & $\begin{array}{l}\text { Relative } \\
\text { change }(\%)\end{array}$ & 124.47 & 26.05 & 78.30 & 132.67 & -21.81 & 10.59 \\
\hline \multirow{3}{*}{ BD 7012} & Control & $0.19 \pm 0.02$ & $36.5 \pm 2.1$ & $1.3 \pm 0.06$ & $272.6 \pm 17.9$ & $197.5 \pm 13.5$ & $9.9 \pm 0.2$ \\
\hline & waterlogged & $0.18 \pm 0.02$ & $52.5 \pm 5.1$ & $1.6 \pm 0.09$ & $438.1 \pm 43.7$ & $194.9 \pm 8.7$ & $14.7 \pm 0.1$ \\
\hline & $\begin{array}{l}\text { Relative } \\
\text { change (\%) }\end{array}$ & -0.65 & 43.89 & 27.34 & 60.69 & -1.29 & 48.20 \\
\hline
\end{tabular}

\pm values indicate the standard deviation $(\mathrm{SD})$ of respective means 
Table 3. Enzymatic activities among the sesame genotypes during recovery period

\begin{tabular}{|c|c|c|c|c|c|c|c|}
\hline Genotypes & Treatment & $\begin{array}{l}\text { POD } \\
(\mu \mathrm{mol} / \\
\mathrm{min} / \mathrm{mg} \\
\text { protein })\end{array}$ & $\begin{array}{l}\text { CAT } \\
(\mu \mathrm{mol} / \\
\mathrm{min} / \mathrm{mg})\end{array}$ & $\begin{array}{l}\text { APX } \\
(\mu \mathrm{mol} / \\
\text { min/mg } \\
\text { protein })\end{array}$ & $\begin{array}{l}\text { GPX } \\
(\mathrm{nmol} / \\
\text { min/mg } \\
\text { protein) }\end{array}$ & $\begin{array}{l}\text { SOD }(\mathrm{U} / \mathrm{mg} \\
\text { protein }\end{array}$ & $\begin{array}{l}\text { MDA } \\
(\mathrm{nmol} / \mathrm{g} \\
\mathrm{FW})\end{array}$ \\
\hline \multirow{5}{*}{ BD 6980} & Control & $2.4 \pm 0.2$ & $17.5 \pm 2.4$ & $3.7 \pm 0.1$ & $301.0 \pm 29.8$ & $100.1 \pm 10.8$ & $17.5 \pm 1.9$ \\
\hline & waterlogged & $3.4 \pm 0.2$ & $42.7 \pm 2.8$ & $5.8 \pm 0.5$ & $291.7 \pm 5.0$ & $147.5 \pm 4.1$ & $21.2 \pm 1.8$ \\
\hline & $\begin{array}{l}\text { Relative } \\
\text { change (\%) }\end{array}$ & 38.60 & 143.81 & $\mathbf{5 9 . 3 7}$ & -3.10 & 47.31 & 21.42 \\
\hline & Control & $1.1 \pm 0.15$ & $41.2 \pm 5.8$ & $7.6 \pm 0.6$ & $592.4 \pm 68.1$ & $172.9 \pm 24.4$ & $12.2 \pm 1.1$ \\
\hline & waterlogged & $1.7 \pm 0.29$ & $34.9 \pm 2.9$ & $9.2 \pm 0.9$ & $673.2 \pm 36.1$ & $232.9 \pm 30.0$ & $14.8 \pm 1.5$ \\
\hline \multirow[t]{2}{*}{ BD 6985} & $\begin{array}{l}\text { Relative } \\
\text { change (\%) }\end{array}$ & 50.80 & -15.25 & 21.58 & 13.65 & 34.66 & 17.52 \\
\hline & Control & $2.2 \pm 0.2$ & $12.9 \pm 2.0$ & $4.8 \pm 0.4$ & $433.3 \pm 15.8$ & $100.6 \pm 8.1$ & $18.3 \pm 1.5$ \\
\hline \multirow[t]{3}{*}{ BD 6992} & waterlogged & $2.3 \pm 0.1$ & $26.2 \pm 3.1$ & $6.0 \pm 0.2$ & $464.6 \pm 16.1$ & $169.8 \pm 10.6$ & $22.0 \pm 1.7$ \\
\hline & $\begin{array}{l}\text { Relative } \\
\text { change (\%) }\end{array}$ & 8.82 & 103.08 & 24.00 & 7.21 & 68.80 & 20.55 \\
\hline & Control & $2.0 \pm 0.08$ & $11.5 \pm 0.8$ & $2.7 \pm 0.3$ & $208.8 \pm 7.3$ & $51.7 \pm 4.6$ & $8.4 \pm 0.7$ \\
\hline \multirow[t]{2}{*}{ BD 7012} & waterlogged & $2.2 \pm 0.15$ & $15.5 \pm 1.2$ & $2.9 \pm 0.3$ & $310.7 \pm 7.9$ & $101.4 \pm 9.4$ & $10.7 \pm 0.4$ \\
\hline & $\begin{array}{l}\text { Relative } \\
\text { change (\%) }\end{array}$ & 10.95 & 34.58 & 3.78 & 48.84 & 96.14 & 26.67 \\
\hline
\end{tabular}

\pm Values indicate the standard deviation $(\mathrm{SD})$ of respective means

Waterlogging stress can cause stomata closure, which will reduce $\mathrm{CO}_{2}$ availability in the leaves and inhibit photosynthesis (Crawford, 1978). Thus, excessive excitation energy in chloroplasts could increase the generation of ROS and induce oxidative stress (Gossett et al., 1999). Hence, the ROS production in plants will increase under flooding stress (Ahmed et al., 2002). In the present study, the injury of biological lipid by ROS, as indicated by MDA content clearly increased in waterlogged plant. On the other hand, different antioxidant activities showed their capacity of defense system against ROS. It has been assumed that SOD has a control role in the defense against oxidative stress (Scandalias, 1993; Zhang et al., 2007). SOD removes superoxide radical by catalyzing its dismutationand one superoxide being reduced to $\mathrm{H}_{2} \mathrm{O}_{2}$ and another oxidized to $\mathrm{O}_{2}$ (Hassanuzzaman et al., 2012). Catalase (CAT) is capable to dismutase two molecules of $\mathrm{H}_{2} \mathrm{O}_{2}$ to water and oxygen and thus it is considered as an efficient ROS detoxifier (Hassanuzzaman et al., 2012). Peroxidase (POD) also decomposed the $\mathrm{H}_{2} \mathrm{O}_{2}$ (Hwang et al., 1999). APX is vital for antioxidant defense because it is involved the maintaining the ascorbate pool and ascorbate has vital role in development of plant stress tolerance to adverse environmental conditions (Pastori et al., 2003). The GPX is another vital enzyme of 
antioxidant defense system and it can efficiently scavenge $\mathrm{H}_{2} \mathrm{O}_{2}$ and thus provide protection against stress (Brigelius-Flohe and Flohe, 2003).

Although, different antioxidant enzyme activities were found inconsistant in the present study but most of the antioxidant enzyme activities showed an increasing trend in waterlogged plant than that of control plant in all the genotypes. It is indicated that all the four genotypes seems to be moderately tolerant to waterlogging. Furthermore, genotypes BD 6980 having lower amount of MDA and simultaneously showed higher antioxidant activities which indicated highly tolerant to waterlogging stress.

\section{Yield and yield components}

Seed yield was reduced in all the genotypes due to imposition of waterlogging i.e., 3.6 to $6.4 \mathrm{~g} \mathrm{plant}^{-1}$ ) whereas it was 6.5 to $9.9 \mathrm{~g} \mathrm{plant}^{-1}$ in control condition (Table 4). But reduction increment was found minimum (24\%) in BD 7012 and maximum in BD 6980 (44\%). Among the seed yield components, number of capsule per plant largely contributed to the seed yield which also showed similar trend with that of seed yield. Yield potentiality might due to genetic differences among the genotypes. Although BD 6980 was identified as highly tolerant genotype to waterlogging considering waterlogging tolerance and enzymatic activities but it produced lower seed yield in waterlogging as well as control condition. Setter and Waters (2003) also reported that highly tolerant lines may be low yielding genotype. With respect to reproductive success, a decline of photosynthesis will eventually result in limited resource availability for reproduction in parental and gametophytic tissues due to a reduction in energy reserves leading to plant starvation (Young et al., 2004; Sumesh et al., 2008). Thus, generating high yielding and stress-tolerant crops requires a thorough understanding of the metabolic and developmental processes involved not only in stress responses but also in energy regulation (Hirayama and Shinozaki, 2010).

Table 4. Seed yield and yield components of sesame genotypes under waterlogging at vegetative stage

\begin{tabular}{l|l|r|r|r|r|r}
\hline Genotypes & \multicolumn{1}{|c|}{ Treatment } & $\begin{array}{c}\text { Plant height } \\
\text { at harvest (cm) }\end{array}$ & $\begin{array}{c}\text { Capsule/pla } \\
\text { nt (no.) }\end{array}$ & $\begin{array}{c}\text { Seeds/ } \\
\text { Capsule } \\
\text { (no.) }\end{array}$ & $\begin{array}{c}\text { 1000 seed } \\
\text { wt. (g) }\end{array}$ & $\begin{array}{c}\text { Seed } \\
\text { wt./plant } \\
(\mathrm{g})\end{array}$ \\
\hline \multirow{3}{*}{ BD 6980 } & Control & $89.9 \pm 10.6$ & $43.8 \pm 3.9$ & $69.6 \pm 4.8$ & $3.10 \pm 0.1$ & $6.5 \pm 0.9$ \\
& waterlogged & $68.9 \pm 6.3$ & $23.0 \pm 2.7$ & $71.8 \pm 8.5$ & $3.12 \pm .02$ & $3.6 \pm 0.3$ \\
& Relative change & & & & & \\
& $\mathbf{( \% )}$ & $\mathbf{- 2 3}$ & $\mathbf{- 4 7}$ & $\mathbf{3}$ & $\mathbf{1}$ & $\mathbf{- 4 4}$ \\
\hline \multirow{3}{*}{ BD 6985 } & Control & $88.0 \pm 12.8$ & $52.5 \pm 3.4$ & $78.0 \pm 5.6$ & $2.78 \pm 0.2$ & $7.4 \pm 0.6$ \\
& waterlogged & $72.4 \pm 12.8$ & $30.2 \pm 1.5$ & $75.0 \pm 5.2$ & $2.78 \pm 0.2$ & $5.4 \pm 0.5$ \\
& Relative change & & & & & -27 \\
\hline
\end{tabular}




\begin{tabular}{|c|c|c|c|c|c|c|}
\hline Genotypes & Treatment & $\begin{array}{c}\text { Plant height } \\
\text { at harvest }(\mathrm{cm})\end{array}$ & $\begin{array}{c}\text { Capsule/pla } \\
\text { nt (no.) }\end{array}$ & $\begin{array}{c}\text { Seeds/ } \\
\text { Capsule } \\
\text { (no.) }\end{array}$ & $\begin{array}{l}1000 \text { seed } \\
\text { wt. }(\mathrm{g})\end{array}$ & $\begin{array}{c}\text { Seed } \\
\text { wt./plant } \\
\text { (g) }\end{array}$ \\
\hline \multirow{3}{*}{ BD 6992} & Control & $91.7 \pm 4.8$ & $80.3 \pm 3.9$ & $70.6 \pm 4.3$ & $3.12 \pm 0.1$ & $9.9 \pm 1.2$ \\
\hline & waterlogged & $73.1 \pm 4.9$ & $36.5 \pm 3.7$ & $64.0 \pm 6.2$ & $2.88 \pm 0.2$ & $5.8 \pm 0.3$ \\
\hline & $\begin{array}{l}\text { Relative change } \\
(\%)\end{array}$ & -20 & -55 & -9 & -7 & -41 \\
\hline \multirow{3}{*}{ BD 7012} & Control & $76.3 \pm 6.1$ & $51.8 \pm 8.5$ & $63.3 \pm 6.4$ & $2.8 \pm 0.2$ & $8.5 \pm 0.5$ \\
\hline & waterlogged & $74.8 \pm 3.2$ & $39.3 \pm 4.5$ & $77.6 \pm 7.9$ & $2.75 \pm 0.1$ & $6.4 \pm 0.5$ \\
\hline & $\begin{array}{l}\text { Relative change } \\
(\%)\end{array}$ & -2 & -24 & 23 & -2 & -24 \\
\hline
\end{tabular}

\pm values indicate the standard deviation (SD) of respective means

\section{CONCLUSION}

All genotypes showed positive waterlogging tolerance indices in root, stem, leaf and petiole but in terms of root showed better performance. Genotype BD 6980 having lower amount of MDA alongside higher antioxidant (SOD, CAT, POD, APX, GPX) activities is considered as highly tolerant and other three genotypes are moderately tolerant under water logging condition. Seed yield reduced in all the genotypes due to imposition of waterlogging but minimum reduction was observed in BD 7012 (24\%).

\section{REFERENCES}

Ahmed, S., Nawata, E., Hosokawa, M. and Sakuratain, T. 2002. Alterations of photosynthesis and some antioxidant enzymatic activities of mungbean subjected to waterlogging. Plant Science, 163: 117-123

Armstrong, W. 1979. Aeration in higher plants. Advances in Botanical Research, 7:225-332

Barrett-Lennard, E. G. 2003. The interaction between waterlogging and salinity in higher plants: causes, consequences and implications. Plant and soil, 253: 35-54

Boru, G., van Ginkel, M., Trethowan, R. M., Boersma, L. and Kronstad, W. E. 2003. Oxygen use from solution by wheat genotypes differing in tolerance to waterlogging. Euphytica, 132: 151-158

Bowler, C., Van Montagu, M. and Inze, D. 1992. Superoxide dismutase and stress tolerance Annu Rev Plant Physiol. Plant Molicular Biology, 43:83-116

Bradford, M. M. 1976. A rapid and sensitive method for the quantitation of microgram quantities of protein utilizing the principle of protein-dye binding. Analytical Biochemistry. 72:248-254

Colmer, T. D. and Islam, A. K. M. T. 2002. Development of cereal tolerant to salinity and waterlogging $8^{\text {th }}$ National Conference and Workshop on the Productive Use and 
R. R. Saha et al.

Rehabilitation of Saline Lands (PURSL), Fremantle, Western Australia. 16-20 Septermber 2002. Promaco Conventions, pp. 241-247

Craford, R. M. M. 1978. Metabolic adaptations to anoxia. In: Hook DD and Crawford R. M. M. (eds) Plant life in Anaerobic Environments. Ann Arbor, Michigan: Ann Arbor Science Publication, pp 119-136.

Csiszar, J., Lantos, E., Tari, I., Madoşa, E., Wodala, B., Vashegyi, A., Horvath, F., Pecsvaradi, A., Szabo, M., Bartha, B., Galle, A., Lazăr, A., Coradini, G., Staicu, M., Postelnicu, S., Mihacea, S., Nedelea, G.and Erdei, L. 2007. Antioxidant enzyme activities in Allium species and their cultivars under water stress. Plant, Soil and Environment, 53 (12): 517-523

Elia, A. C., Galarini, R., Taticchi, M. I., Dorr, A. J. M. and Mantilacci, L. 2003. Antioxidant responses and bioaccumulation in Ictalurus melas under mercury exposure. Ecotoxicology and Environmental Safety, 55(2): 162-167

Gossett, D. R., Millhollon, E. P. and Luca, M. C. 1999. Antioxidant response to $\mathrm{NaCl}$ stress in salt-tolerant and salt-sensitive cultivars of cotton. Crop Science, 34: 706-714

Hasanuzzama, M., Hossain, M. A., Teixeira da Silva, J. A. and Fuita, M. 2012. "Plant responses and tolerance to a biotic oxidative stress: antioxidant defense is a key factor" In: Crop Stress and Its Management: Perspectives and Strategies. V. Bandi, A. K. Shanker, C. Shanker, and M. Mandapaka, Eds., pp. 261-316

Hasanuzzaman, M., Hossain, M. A. and Fujits, M. 2011. "Nitric oxide modulates antioxidant defense and the methylglyoxal detoxification system and reduces salinity-induced damage of wheat seedling," Plant Biotechnology Reports. 5:353-365

Hasanuzzaman, M., Hossain, M. A.,Terixeira da Solva, J. A. and Fujita, M. 2012. "Plant responses and tolerance to abiotic oxidative stress: antioxidant defense is a key factor," In: Crop Stress and Its Management: Perspectives and Strategies. V. Bandi, A.K. Shanker, C. Shanker, and M. Mandapaka, Eds., pp. 261-316, Springer, Berlin, Germany

Heath, R. L. and Packer, L. 1968. Photo-peroxidation in isolated chloroplasts. I. Kinetics and stoichiometry of fatty acid peroxidation. Archives of Biochemistry and Biophysics, 125(1): 189-198

Hemeda, H. M. and Klein, B. P. 1990. Effects of naturally occurring antioxidants on peroxidase activity of vegetable extracts. Journal of Food Science, 55: 184-185

Hirayama, T. and Shinozaki, K. 2010. Research on plant abiotic stress responses in the postgenome era: past, present and future. Plant Journal, 61:1041-1052

Hocking, P. J., Reicosky, D. C. and Meyer, W. S. 1985. Nitrogen status of cotton subjected to two short term periods of waterlogging of varying severity using a sloping plot water table facility. Plant and Soil, 87: 375-221

Hodgson, A. S. and Chan, K. Y. 1982. The effect of short term waterlogging during furrow irrigation of cotton in a cracking grey clay. Australian Journal of Agricultural Research, 33: 109-116 
Hwang, S. Y., Lin, H. W.,Chern, R. H., LoH. F. and Li, L. 1999. Reduced susceptibility to waterlogging together with high-light stress is related to increases in superoxide dismutase and catalase activities in sweet potato. Plant Growth Regulation, 27:167-172

Kramer, P. J. 1951. Causes ofinjury to plants resulting from flooding of soil. Plant Physiology, 26:722-736

Nakano, Y. and Asada, K. 1981. Hydrogen peroxide is scavenged by ascorbate-specific peroxidase in spinach chloroplasts. Plant \& Cell Physiology, 22: 867-880.

Orchard, P. W., Jessop, R. S. and So, H. B. 1986. The response of sorghum and sunflower to short-term waterlogging. 4. Water and nutrient-uptake effects. Plant and Soil, 91: 87100

Pastori, G. M., Kiddle, G. and Antoniw, J. 2003. Leaf vitamin C contents modulate plant defense transcripts and regulate genes that control development through hormone signaling. Plant Cell, 15(4): 939-951

Rochester, I. 2001. NUTRI pak: a practical guide to cotton nutrition Australian Cotton Cooperative Research Centre, Narrabri, NSW

Saha, R. R., Ahmed, B., Aziz M. A. and Hossain, M. A. 2010. Screening of sesame genotypes for water logging tolerance. Bangladesh Agronomy Journal, 13 (1 \& 2): 8393

Scandalias, J. G. 1993. Oxygen stress and superoxide dismutase. Plant Physiology, 101(1):712

Setter, T. L. and Waters, I. 2003. Review of prospects for germplasm improvement for water logging tolerance in wheat, barley and oats. Plant and soil, 253: 1-34

Spitz, D. R. and Oberley, L. W. 1989. An assay for superoxide dismutase activity in mammalian tissue homogenates. Analytical Biochemistry, 179: 8-18

Sumesh, K., Sharma-Natu P., Ghildiyal, M. 2008. Starch synthase activity and heat shock protein in relation to thermal tolerance of developing wheat grains. Plant Biology, 52:749-753

Wiengweera, A. and Greenway, H. 2004. Performance of seminal and nodal roots of wheat in stagnant solution: $\mathrm{K}^{+}$and $\mathrm{P}$ uptake and effects of increasing 0-2 partial pressures around the shoot on nodal root elongation. Journal of Experimental Botany, 55: 21212129

Young L. W., Wilen R. W., Bonham-Smith P. C. 2004. High temperature stress of Brassica napus during flowering reduces micro-and megagametophyte fertility, induces fruit abortion, and disrupts seed production. Journal of Experimental Botany, 55:485-495

Zhang, G. G., Tanakamaru, K. Abe, J. and Morita, S. 2007. Influence of water logging on some anti-oxidative enzymatic activities of two barley genotypes differing in anoxia tolerance. Acta Physiologiae Plantarum, 29: 171-176 